\title{
CORRIGENDUM TO: Seeing with the mind's eye: top-down, bottom-up, and conscious awareness
}

\section{Alumit Ishai}

FI000 Biology Reports 2013,2:34.I (doi:10.34I0/B2-34.I)

Address: Institute of Neuroradiology, University of Zurich, Winterthurerstrasse 190, 8057 Zurich, Switzerland

ORIGINAL CITATION:

Fl000 Biology Reports 2010, 2:34 (doi:10.34I0/B2-34)

This is an open-access article distributed under the terms of the Creative Commons Attribution-Non Commercial License

(http://creativecommons.org/licenses/by-nc/3.0/legalcode), which permits unrestricted use, distribution, and reproduction in any medium, provided the original work is properly cited. You may not use this work for commercial purposes.

The electronic version of this article is the complete one and can be found at: http://fl000.com/prime/reports/b/2/34

The PDF of this article can be found at: http://fl000.com/prime/reports/b/2/34/pdf

\section{CORRIGENDUM:}

The author would like to acknowledge that this article is a modified version of their article previously published in Archives Italiennes de Biologie. Ishai A: Seeing faces and objects with the “mind's eye". Archives Italiennes de Biologie 20 I0 I 48:I-9. 